\title{
The Relationship of BIST Sector Indices with Exchange Rate Volatility
}

\author{
Necmiye Serap VURUR ${ }^{\mathrm{a}^{*}}$ \\ a Department of Accounting and Finance Management, School of Applied Sciences, Afyon Kocatepe University, \\ Afyonkarahisar,
}

\begin{abstract}
A B S T R A C T
Through globalization, the increased integration in financial markets has made the relationship between exchange rate and stocks important. The study aims to model the exchange rate volatility using daily data for the period 04.01.2010-15.10.2020 and investigate the causality relationship between sector returns and exchange rate return volatility. In order to model the volatility of the exchange rate return series, the GARCH model was used to reveal the possible asymmetry feature in the series. As a result of the model applications, GARCH $(2,2)$ was determined as the most suitable model to measure volatility modelling. Then, the Granger causality test was used to see whether there is a relationship between BIST sector return indices and exchange rate return volatility. As a result of the study, one notes that there is a unidirectional causality from the exchange rate return volatility series to the service, technology, and industrial sector indices. There is a bidirectional causality relationship between the financial sector index and the exchange rate return volatility series. It is noteworthy that the causality relationship between the BIST100 index and the exchange rate is towards the volatility of the exchange rate return series from the BIST 100 index, unlike the sector indices. According to this result, it is seen that the changes in the dollar exchange rate affect the decisions of the investors who will invest in the relevant index. The results show that in the case of Turkey, mostly traditional theories are valid.
\end{abstract} A R T I C L E I N F O Keywords: Stock Markets, Exchange Rate, Exchange Rate Volatility, Causality, Turkey *serapvurur@aku.edu.tr

\author{
Article history: \\ Received 12.01.2021 \\ Revised 19.03.2021 \\ Accepted 23.04.2021 \\ DOI:https://doi.org/10.51410/jcgirm.8.1.4
}

\section{INTRODUCTION}

Exchanges act as financial intermediaries between units with fund surplus and units in need of funds. Increasing resource needs in developing countries are attempted to be met from international capital flows. In recent years, the interaction between national stock exchanges and exchange rates has increased due to increased capital flows between global financial markets.

The relationship between stock markets and the exchange rate has been explained in the literature with the traditional approach and portfolio balance approach (Tian and Ma, 2010: 491). The traditional 
approach developed by Dornbusch and Fisher (1980) states that a change in the exchange rate will affect stock prices; in other words, there is a causality relationship from exchange rate to stock prices. In the Traditional Approach, the changes in exchange rates affect the enterprises' stock prices together with the international competition. According to the Traditional Approach, a one-unit increase in exchange rates will cause an increase in the exports of the relevant countries. This situation will cause the stock prices to increase along with the income of the enterprises. Therefore, it is concluded that there is a positive and significant relationship between exchange rates and stock prices as well as a causality relationship from exchange rates to stock prices. In addition, according to this theory, it is thought that a decrease in the exchange rate in the exporting countries will decrease the profitability of the enterprises and affect the stocks negatively. In importing countries, the exchange rate decrease will increase the enterprises' profits and cause the stocks to be positively affected (Obben et al., 2006: 148, Alacahan and Akarsu, 2019: 134). In the portfolio approach developed by Branson (1983), it is stated that there is a negative relationship between stock prices and exchange rate, and the causality relationship is from stock price to exchange rate. According to this view, increasing national stock prices will increase the local currency's demand, causing foreign stocks to be sold and being replaced by national stocks. This situation causes a downward pressure on the exchange rate and a decrease in its value. (Berke, 2012: 244; Abdalla and Murinde, 1997: 25). Turkey's economy has turned to liberalization since the 1980s. Due to this liberalization in financial markets, exchange rate volatility has been one of the factors affecting the real economy. Exchange rate volatilities affect the production costs and profitability of firms as well as have an impact on stock market returns. Since the US national currency, the dollar, is used as the international reserve currency, decisions taken by the US government and the US Central Bank FED also affect the economies of other underdeveloped, developing, and developing countries. Turkey's economy, through changes in the dollar rate, is among the most affected countries. For this reason, the value of the US dollar against the Turkish Lira was used as the exchange rate in the study. The reasons for this study can be grouped under three headings:

1. First, the study will show the direction of the interaction with the exchange rate on the performance of the stock market sectors.

2. Secondly, it will ensure that the sectors on which exchange rate movements are effective will be revealed in terms of portfolio management.

3. Finally, at the end of 2017, the share of foreign exchange in Turkey was 65\%, in 2018 it was 65.1\%, and $61 \%$ at the end of 2019. At the end of the first month of 2020 this stood at 59.5\%. Therefore, the results to be obtained will attract the attention of foreign portfolio investors who are worried about exchange rate risks.

In previous studies, the relationship between exchange rates and stock markets is not clear. Different conclusions have been reached in various countries on the subject. The aim of the study, in relation to sectors in Turkey's economy, is to investigate which of the traditional approach or portfolio balance theory is valid. This study is different from other studies in the literature in that it investigates the 
exchange rate theories based on both the whole index and the sector index and by creating a volatility series for the exchange rate.

The next part of the study is organized as follows: In the second section, the relevant literature is reviewed, and the main findings are presented. In the third section, the data and methodology used in the study are explained. The fourth section gives empirical evidence of the relationship between exchange rates and sector indices in Turkey. In the conclusion part, the findings were discussed and suggestions were included.

\section{LITERATURE REVIEW}

This section includes empirical studies investigating the relationship between exchange rates and stock market indices of various countries. While most studies in the literature focus on the relationship using only two variables, such as exchange rate and stock prices, some studies investigate the effect of multiple real economic variables on stock returns. Considering the studies in the literature, one notes that there is no consensus on this issue.

Bahmani-Oskooee and Sohrabian (1992) found a causality relationship between US stock prices and the US dollar's effective exchange rate in the short term. Amihud (1994) and Bartov and Bohner (1994) found that changes in US dollar exchange rates explain firms' current stock returns with a delay. While Abdalla and Murinde (1997), who focused on emerging markets, found uni-directional causality from exchange rates to stock prices in Korea, Pakistan and India. The Philippines' causality relationship took place from stock prices to exchange rates. Tabak (2006) found that in Brazil, which abandoned the fixed exchange rate regime in 1999, there is a linear Granger causality with a negative correlation between stock prices and exchange rates, and this situation supports the portfolio approach. Horobet and Ilie (2007) found that a causality relationship existed before 2004 when the National Bank of Romania controlled the exchange rate. According to the study, the stock exchange adapts to changes in exchange rates after one month. Ghazali et al. (2008) analyzed the relationship between stock prices and exchange rates in Malaysia for the period between 2005 and 2007 using the Johansen cointegration method. They determined that there was no long-term equilibrium relationship between these two variables. Using the Engle-Granger and Toda-Yamamoto tests Ghazali (2018) detected a unidirectional causality between stock prices and the exchange rates. Aliyu (2009) examined the long and short-term relationship between stock prices and exchange rates in Nigeria for 2001-2008 and found a cointegration relationship. As a result of the causality tests, it was found that there is a solid bidirectional long-term relationship between these two variables. Tian and Ma (2010) demonstrated that since the Chinese exchange rate regime became flexible, there has been cointegration between the Shanghai A Stock Index and the Renminbi's US dollar and Hong Kong index. Both the exchange rate and the money supply have positively correlated with the stock price. Kutty (2010), on the other hand, found that the results of Granger causality tests in Mexico are the cause of the exchange rates of stock prices in the short term, but there 
is no long-term a relationship between these two variables. In their study, Lean et al. (2011) examined the relationship between exchange rates and stock prices in eight Asian countries, found cointegration between these two variables only in Korea, and the existence of a weak uni-directional Granger causality from exchange rates to stocks. Kabir et al. (2014) tried to determine whether there is a significant relationship between stock prices and macroeconomic variables and foreign stock prices in an economy. Their study with the quarterly data of 1991-2010 found a significant relationship between Malaysian stock prices and exchange rate and foreign stock prices. Among these, the exchange rate was the most determining variable. Sharma (2016) tested the negative relationship between India's stock return and the exchange rate with correlation analysis. Akbar, Iqbal, and Noor (2019) examined the relationship between stock prices and exchange rates using monthly data from the Pakistani economy. They used the VAR model and the Bayesian VAR model as their analysis method. The findings obtained from the analysis concluded that while no long-term relationship between variables was found, negative fluctuations in the exchange rate caused a decrease in stock prices.

Some studies reveal the relationship between stocks (stock exchanges) and exchange rates in samples of various countries, regions and economies using their volatility spillover (See O'Donnell \& Morales 2009; Lee et al. 2011; Walid et al. 2011; Andrikopoulos et al. 2014; Sui and Sun 2016; Sikhosana and Aye 2018; Akdağ and Yıldırım 2019; Şenol 2020; Ozdemir 2020; Maura and Trebelsi 2020; Baranidharan and Alex 2020). O'Donnell and Morales (2009) analyzed the volatility spillover between exchange rates and stocks in the Czech Republic, Hungary, Poland, and Slovakia sample. In the study, it was seen that there was no volatility spillover effect among the sample countries, and the asymmetric spillover effect was positive from stock returns to exchange rates. In another study, Lee et al. (2011) analyzed the relationship between stock prices and exchange rates using the STCCGARCH model in their study on many Asian countries. They found that there were significant price transitions from the stock market to the foreign exchange market for Indonesia, Korea, Malaysia, Thailand and Taiwan. Walid et al. (2011) investigated the dynamic relationship between stock price volatility and exchange rate changes in Hong Kong, Singapore, Malaysia and Mexico using the Markov Regime Switching model. The study results showed that the relationship between stocks and exchange rate markets depends on their regime, and the volatility in stocks responds asymmetrically to the events in the exchange rate markets. Andrikopoulos et al. (2014) examined the volatility spillover between stocks and exchange rates in a sample of countries experiencing foreign debt crises and financial problems in the Eurozone. The results reveal a mutually asymmetric volatility spillover between exchange rate and stock markets, and they mutually affect each other. Sui and Sun (2016) investigated the relationship between exchange rates and stocks in a BRICS sample (Brazil, Russia, India, China and South Africa) and US countries. In the study, the short-run spillover effect is from exchange rate shocks to stock returns for all BRICS countries. Ozdemir (2020) and Mroua and Trabelsi (2020) found different results in the BRICS countries' sample. Ozdemir (2020) revealed a bidirectional causality relationship between the stock 
index and exchange rates of BRICS-T countries, excluding Brazil and India, both symmetrically and asymmetrically. The study of Mroua and Trabelsi (2020) shows that exchange rate changes significantly impact the past and present volatility of BRICS stock indices. In addition, ARDL forecasts show that exchange rate movements significantly impact the short and long-term stock market indices of all BRICS countries. Baranidharan and Alex (2020) analyzed the exchange rate volatility spillover on the South African Stock Exchange. The study concluded that changes in exchange rates would have a low effect on the Johannesburg stock exchange returns. Akdag and Y1ldirım (2019) studied the volatility spillover in Turkey samples. Their studies investigated the effect of positive and negative shocks in the dollar exchange rate on the BIST Industry and BIST Finance index. According to the Granger causality analysis result, there is bidirectional causality between variables. As a result of the Hatemi-J causality analysis, a bidirectional causality from positive and negative shocks in the dollar exchange rate to positive and negative shocks in both BIST Industry and BIST Finance indexes was determined. When Şenol (2020) used the causality test in variance, volatility spillover and the DCC GARCH method, he concluded a bi-directional relationship between Borsa İstanbul and the exchange rate.

In the literature, studies addressing the exchange rate relations with Turkey stock were investigated. Pekkaya and Bayramoğlu (2008) examined the causality relationship between variables with TRY / USD, ISE-100, and S\&P 500 index data between 1990 and 2007. They found a bidirectionally Granger causality relationship between the exchange rate and the ISE 100 index. Kapusuzoglu and Ibicioglu (2010) examined the relationship between the exchange rate and the ISE National 100 Index and the direction of this relationship with daily data. In the study, as a result of the Johansen cointegration test, it was determined that there is a long-term relationship between the index and the exchange rate, and as a result of the vector error correction model, there is a negative short-term relationship between the index and the exchange rate. As a result of the Granger causality analysis, the authors determined that the exchange rate is the uni-directional Granger cause of the index. Savas and Can (2011) examined the relationship between ISE-100 and Euro-Dollar Parity, Real Effective Exchange Rate. In the study, a causality was determined from ISE 100 index towards Real Effective Exchange Rate, Euro-Dollar Parity with Granger causality test. Berke (2012) investigated the relationship between exchange rate and BIST 100 in 2002: 01 and 2012:07. In his study, he concluded that the portfolio balance approach is valid in Turkey. Ceylan and Şahin (2015) found a strong causality relationship from exchange rate to stock prices at the end of their study to examine the relationship between exchange rate and stock prices. A similar result is seen in Belen and Karamellik's (2016) studies that the exchange rate negatively affects stock prices, and the traditional approach is valid. Urkmez and Karatas (2017) found no long-term relationship between BIST and USD exchange rates. However, it has been concluded that there is a oneway Granger causality relationship between them from the exchange rate to the BIST index. Ilarslan (2018) revealed a negative relationship between exchange rates and stock market index in the short run and a positive relationship in the long run. 
Some studies reveal the relationship between exchange rates and industry indices in the stock exchange. (See Ayvaz 2006; Eyupoglu and Eyupoglu 2018; Akdag and Yıldırım 2019; Kayral 2020; Ugur and Bingol (2020). Since these studies differ in terms of indices used, methods and results obtained, they will be discussed in detail. Ayvaz (2006) investigated the exchange rate relationship with the financial sector index, industry sector index and service sector indices. His study found a long-term stable relationship between the exchange rate and the National 100 index, the exchange rate and the Financial Sector Index, and the exchange rate and the industrial sector index. The study has also shown bidirectional causality between the exchange rate and other stock price indices. Kendirli and Cankaya (2016) examined the relationship between exchange rate and XBANK variables with the Johansen cointegration test and Granger causality test. As a result of the analysis, uni-directional causality from the XBANK index to the exchange rate was determined at the $10 \%$ significance level. In the study of Eyuboglu and Eyuboglu (2018), the relationship between the exchange rates of all industry indices in Borsa Istanbul was tested with the ARDL model. As a result of the analysis, a long-term relationship between the dollar exchange rate and BIST Textile, Leather, Trade, and Technology indices has been determined. Kayral (2020) examined the short and long-term relationship between the BIST city indices and the Dollar and Euro in his study. As a result of applying the ARDL limit test, a long-term relationship with other indices other than BIST Ankara and Euro has been detected. Another result obtained is that there is a positive relationship between Izmir City Index and the Euro. In the studies of Ugur and Bingol (2020), the relationship between the financial sector index, leasing and factoring index, insurance index, banking index, real estate investment trust index, holding and investment trust index and the currency basket consisting of Dollar-Euro was determined by the frequency distribution causality test. As a result of the study, a causality relationship from stocks to exchange rates was found. In the study, it was concluded that the portfolio balance approach is valid.

There are not enough studies in the literature that reveal the relationship between exchange rate volatility and sector indices. Therefore, our study will focus on the relationship between exchange rate volatility and industry returns.

\section{DATA}

This study investigates the effect of exchange rate volatility on BIST sector stock indices. As determined by the Central Bank of the Republic of Turkey, sector indices, service, finance, and technology industry are the main sector indices, and the overall stock market national BIST 100 Index represents the data. As the foreign exchange rate variable, the US dollar (USD) value in Turkish Lira (TL) was taken as it is heavily traded in the country. The daily data for the period $07.01 .2011-15.10 .2020$ were analyzed by taking their logarithm in the study. Data for the analysis of the Republic of Turkey Central Bank (www.evds2.tcmb.gov.tr) was taken. Eviews 11 package program was used in the analysis. Information about the variables included in the study is given in Table 1. 
Table 1: Variables and Abbreviations Included in the Study

\begin{tabular}{|c|c|}
\hline Variables & Abbreviation \\
\hline United States Dollar Return & USDR \\
\hline BIST 100 Index Return & RBIST100 \\
\hline BIST Industrial Index Return & RBISTIND \\
\hline BIST Services Index Return & RBISTSERV \\
\hline BIST Financial Index Return & RBISTFIN \\
\hline BIST Technology Index Return & RBISTTEC \\
\hline
\end{tabular}

Source: Authors' Compilation

Graphical representation of the variables used in the study is given in figure 1.

USDRV
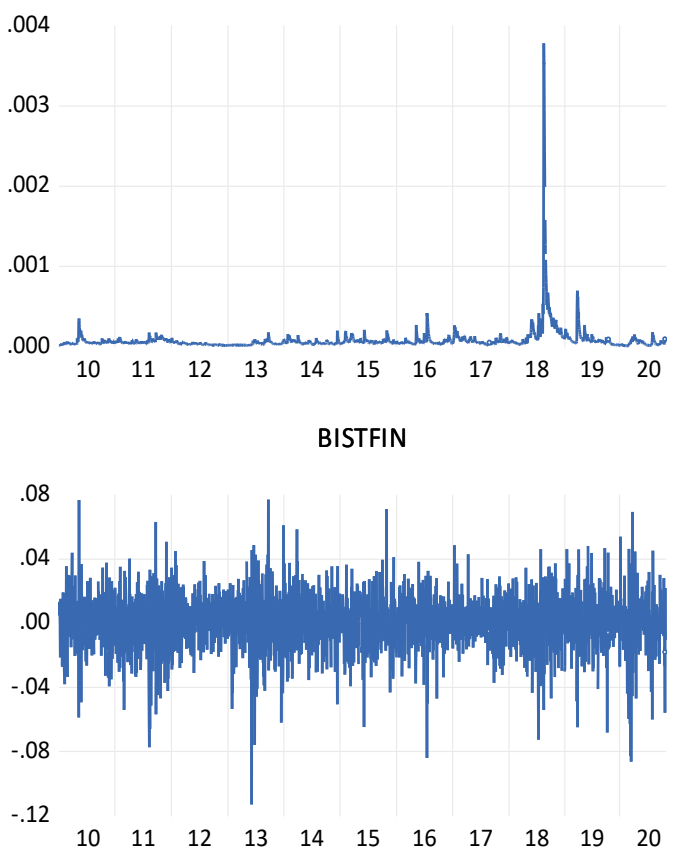

BISTTEC

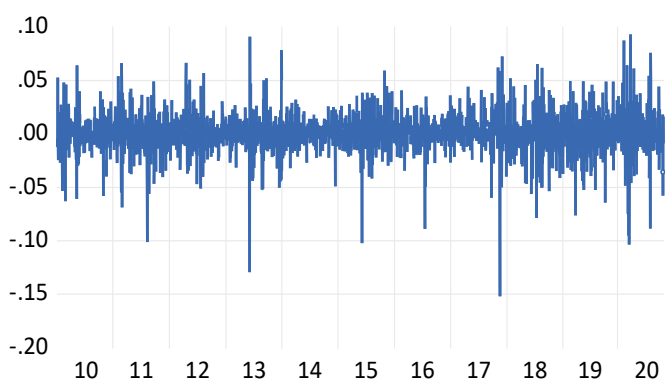

BISTSERV

.08

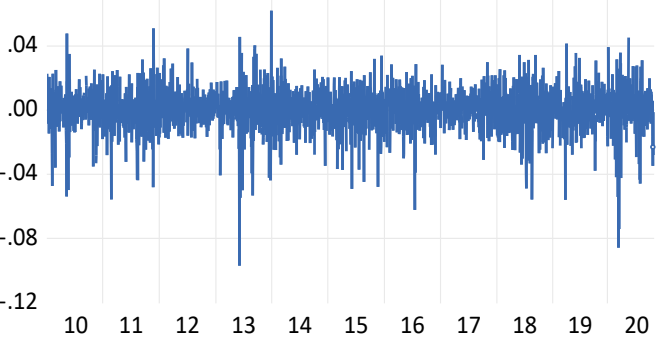

BISTIND

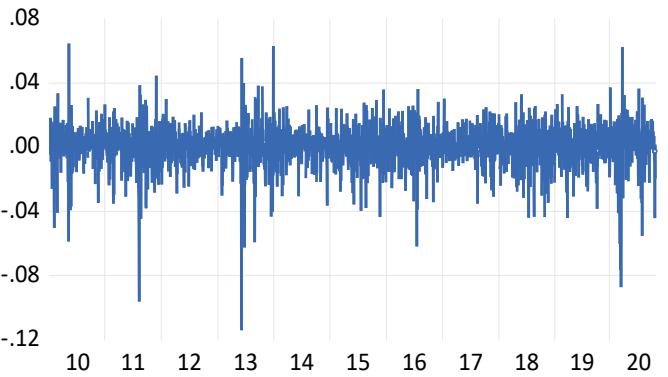

BIST100

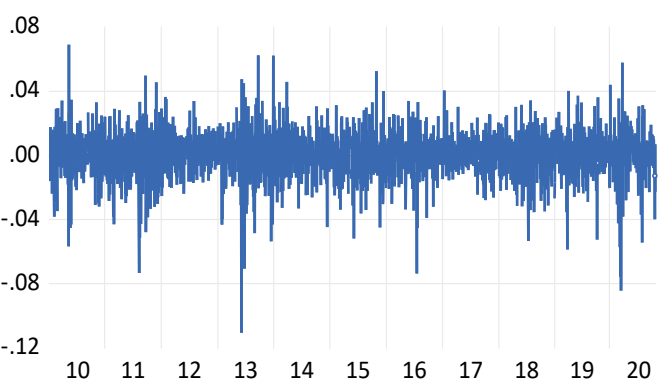

Figure 1. Series Return Change Graph

Table 2: Descriptive Statistics

\begin{tabular}{|l|c|c|c|c|c|c|}
\hline & RBISTSERV & RBISTFIN & RBISTIND & RBISTTEC & RBIST100 & USDR \\
\hline Mean & 0.000370 & 0.000139 & 0.000554 & 0.000887 & 0.000271 & 0.000639 \\
\hline Median & 0.000924 & 0.000445 & 0.001400 & 0.001169 & 0.000912 & 0.000254 \\
\hline Maximum & 0.062034 & 0.077151 & 0.064551 & 0.093636 & 0.068952 & 0.147563 \\
\hline Minimum & -0.096993 & -0.112947 & -0.114010 & -0.151518 & -0.110638 & -0.079965 \\
\hline
\end{tabular}

62 | P a g e Journal of Corporate Governance, Insurance, and Risk Management | 2021, VOL. 8, Series. 1 


\begin{tabular}{|l|c|c|c|c|c|c|}
\hline Std. Dev. & 0.012755 & 0.017082 & 0.012602 & 0.018274 & 0.014333 & 0.008850 \\
\hline Skewness & -0.752626 & -0.415037 & -1.074211 & -0.596745 & -0.613038 & 1.796298 \\
\hline Kurtosis & 7.413410 & 5.769264 & 10.50450 & 9.456235 & 6.938072 & 37.56912 \\
\hline & & & & & & \\
\hline $\begin{array}{l}\text { Jarque- } \\
\text { Bera }\end{array}$ & 2459.787 & 945.4812 & 6893.072 & 4876.523 & 1924.446 & 136647.2 \\
\hline Probability & 0.000000 & 0.000000 & 0.000000 & 0.000000 & 0.000000 & 0.000000 \\
\hline & & & & & & \\
\hline Sum & 1.005677 & 0.377147 & 1.503489 & 2.407108 & 0.734449 & 1.733966 \\
\hline
\end{tabular}

Source: Authors' Compilation

When the skewness, kurtosis, and JB test statistics were examined together, it was determined that all the data included in the study did not conform to the normal distribution. Correlation analysis was performed to determine the direction and degree of the relationship between variables. It means that the closer the correlation coefficient is to 1 and -1 , the stronger the relationship between the variables; however, as it approaches 0 , the relationship between variables gets weaker. Correlation coefficients for the series are given in Table 3.

Table 3: Correlation Between Series

\begin{tabular}{|c|c|c|c|c|c|c|}
\hline & USDR & RBISTTEC & RBISTIND & RBISTFIN & RBISTSERV & RBIST100 \\
\hline USDR & 1,00 & & & & & \\
\hline RBISTTEC & $-0,031266$ & 1,00 & & & & \\
\hline RBISTIND & $-0,023195$ & 0,656966 & 1,00 & & & \\
\hline RBISTFİN & $-0,037376$ & 0,626384 & 0,807136 & 1,00 & & \\
\hline RBISTSERV & $-0,054910$ & 0,596104 & 0,766831 & 0,764489 & 1,00 & \\
\hline RBIST100 & $-0,036641$ & 0,669564 & 0,898705 & 0,971665 & 0,858523 & 1,00 \\
\hline
\end{tabular}

Source: Authors' Compilation

When Table 3 is analyzed, one can see that there is a negative correlation between all sectors and exchange rates. Correlation values between exchange rate return series and industry indices are very close to each other. However, the highest correlation relationship with the exchange rate is seen in the industry sector index. Since the correlation coefficients of the sector indices are positive, it is concluded that the returns of the sector indices move together.

\section{METHODOLOGY}

The relationship between volatility in exchange rates and sectoral stock market index returns is investigated in the study. For this reason, the methodology regarding the Granger causality test, which examines the causality relationship between the General Autoregressive Conditional Heteroskedasticity Models used in the analysis and the series, is included.

\subsection{General Autoregressive Conditional Heteroskedasticity Models}

In traditional time series, the error terms of the predicted models are assumed to have constant variance. It has been observed that the error variance may change over time in econometric 
models aiming to predict financial time series. In the literature, this situation is called heteroscedasticity (changing variance). Engle (1982) developed the ARCH model to better understand the dynamic nature of financial assets and predict variance that changes over time. The ARCH model leaves the constant variance assumption in traditional time series models, allowing the error term variance to change as a function of the squares of the previous period error terms. ARCH models are discussed in two main parts as linear and nonlinear.

$$
\begin{aligned}
& R_{t}=\theta_{t}+\varepsilon_{t} \\
& u_{t} \approx N\left(0, h_{t}\right) \\
& h_{t}=\alpha_{0}+\sum \alpha_{i} \varepsilon_{t-i}^{2}
\end{aligned}
$$

The Linear part is the conditional mean equation (1) showing the change of dependent variable Rt over time. The nonlinear part is the conditional variance equation showing the relationship between the dependent variable conditional variance $h_{t}$ and the error terms lagged values (3). The ARCH equation, while the unknown parameter vector is expressed as $\alpha$, indicates past period prediction errors. The ARCH model led lag value in (3) is named with the value of (q): such as ARCH (1), ARCH (2) (Engle, 1982).

In the ARCH (p) model's empirical applications, many parameters need to be estimated because the delays can go very far back. In order to overcome this drawback, Bollerslev (1986) introduced the Generalized Autoregressive Conditional Variable Variance (GARCH) model. Unlike the ARCH model, this type of model developed by Bollerslev is a volatility model in which conditional variance depends on the lagged values of the squares of the error terms as well as their own lagged values (Johnston and Scott, 2000). The general form of this model, expressed as GARCH (p, q), is as follows (Bollerslev, 1986):

$$
\mathrm{h}_{\mathrm{t}}=\alpha_{0}+\sum_{\mathrm{i}=1}^{\mathrm{q}} \alpha_{\mathrm{i}} \varepsilon_{\mathrm{t}-\mathrm{i}}^{2}+\sum_{\mathrm{i}=1}^{\mathrm{p}} \beta_{\mathrm{i}} \mathrm{h}_{\mathrm{t}-\mathrm{i}}
$$

There are some restrictions on $\alpha$ i parameters in both ARCH models and GARCH models. In these models, $q<0, p \geq 0, \alpha_{0}>0, \alpha_{i} \geq 0$ ( $i=1,2,3, \ldots p$ ) conditions must be met. In addition to these constraints, the sum of the parameters $\alpha_{\mathrm{i}}$ and $\beta_{\mathrm{i}}$ must also be less than one. Providing this constraint shows that the process has a level roots structure (Engle, 2001).

\subsection{Granger Causality Test}

The Granger causality test is a frequently used test to investigate the cause-and-effect relationship between a variable and another variable. Causality analysis analyzes whether one 
variable's delayed values can be used to describe another variable if the $\mathrm{X}$ variables lagged values have a significant effect on the Y variable; X is the Granger cause of Y (Granger, 1988). Granger causality test is performed with the help of the following equations (Gujarati, 2001):

$$
\begin{aligned}
& \mathrm{Y}_{\mathrm{t}}=\mathrm{f}\left(\mathrm{Y}_{\mathrm{t}-\mathrm{i}-\mathrm{i}} \mathrm{X}_{\mathrm{t}-\mathrm{i}}\right)=\alpha_{0}+\sum_{\mathrm{i}=1}^{\mathrm{m}} \alpha_{\mathrm{i}} \mathrm{Y}_{\mathrm{t}-\mathrm{i}}+\sum_{\mathrm{j}=1}^{\mathrm{m}} \beta_{\mathrm{j}} \mathrm{X}_{\mathrm{t}-\mathrm{j}}+\varepsilon_{1 \mathrm{t}} \\
& \mathrm{X}_{\mathrm{t}}=\mathrm{f}\left(\mathrm{X}_{\mathrm{t}-\mathrm{i} \mathrm{i}}-\mathrm{Y}_{\mathrm{t}-\mathrm{i}}\right)=\alpha_{0}+\sum_{\mathrm{i}=1}^{\mathrm{m}} \lambda_{\mathrm{i}} \mathrm{X}_{\mathrm{t}-\mathrm{i}}+\sum_{\mathrm{j}=1}^{\mathrm{m}} \delta_{\mathrm{j}} \mathrm{Y}_{\mathrm{t}-\mathrm{j}}+\varepsilon_{2 \mathrm{t}}
\end{aligned}
$$

Here $m$ indicates the lag length, and the error terms $\varepsilon_{1 \mathrm{t}}$ and $\varepsilon_{2 \mathrm{t}}$ are assumed to be white noise with zero mean and constant variance and common variances of zero. Equation (5) shows causality from $\mathrm{X}$ to $\mathrm{Y}$, and equation (6) shows causality from $\mathrm{Y}$ to $\mathrm{X}$. $\mathrm{H}_{0}$ hypothesis in equation (5); If $\beta_{\mathrm{j}}=0, \mathrm{X}$ is not the cause of $\mathrm{Y}$; H1 hypothesis; one notes that if $\beta_{\mathrm{j}} \neq 0, \mathrm{X}$ is the cause of $\mathrm{Y}$. $\mathrm{H}_{0}$ hypothesis in equation (6); If $\delta_{\mathrm{j}}=0, \mathrm{Y}$ is not the cause of $\mathrm{X}$; $\mathrm{H} 1$ hypothesis; If $\delta_{\mathrm{j}} \neq 0, \mathrm{Y}$ is the cause of $X$.

\section{INTERPRETING THE FINDINGS}

\subsection{Modeling the Volatility of the USD Return Series}

In order to be able to model the volatility of the USD return index, it was first examined whether the time series is stationary or not. The stationarities of the series used in the study are tested by using Augmented Dickey-Fuller (ADF) and Phillips Perron (PP) unit root tests to determine whether the series contain unit root or not. Unit root test results are presented in Table 4

\begin{tabular}{|c|c|c|c|c|c|}
\hline \multirow[t]{2}{*}{ Series } & \multirow[t]{2}{*}{ Level } & \multicolumn{2}{|c|}{$\begin{array}{c}\text { Augmented Dickey-Fuller } \\
\text { (ADF) Testi }\end{array}$} & \multicolumn{2}{|c|}{$\begin{array}{l}\text { Philips-Perron } \\
\text { (PP) Testi }\end{array}$} \\
\hline & & Intercept & Trend Intercept & Intercept & Trend Intercept \\
\hline USDR & Level & $-33.55614 * * *$ & $-33.61735 * * *$ & $-47.3435^{* * *}$ & $-47.8890 * * *$ \\
\hline \multicolumn{6}{|c|}{ Critical Values } \\
\hline \multicolumn{2}{|c|}{$\% 1$} & $-3,4325$ & $-3,9614$ & $-3,4325$ & $-3,9614$ \\
\hline \multicolumn{2}{|c|}{$\% 5$} & $-2,8624$ & $-3,4114$ & $-2,8624$ & $-3,4114$ \\
\hline \multicolumn{2}{|c|}{$\% 10$} & $-2,5672$ & $-3,1275$ & $-2,5672$ & $-3,1275$ \\
\hline
\end{tabular}

Table 4: USD Return Series Unit Root Test Results

Source: Authors’ Compilation

When Table 4 is examined, it reveals that the series do not have a unit root in neither the ADF technique, nor the PP technique (according to the unit root test results of the series with fixed and fixed and trending effects). Thus, it is concluded that the null hypothesis that there is a unit root in the series is rejected and that the level values of the series are stationary I (0). In order to be able to model volatility, it is necessary to examine whether the series has volatility or not. The ARCH LM test determined the presence of 
volatility in the series. The ARMA structure, which are linear stationary stochastic models of the series, should be determined just before the ARCH-LM test. Schwarz Bayesian Information Criterion (SBIC) has been chosen to determine the appropriate ARMA model. 4 lag values were determined for p-value and q value to consider higher led lag values and determine the ideal result. The ARMA results are included in Table 5.

Table 5: ARMA Model Results

\begin{tabular}{|c|c|c|c|c|}
\hline ARMA STRUCTURE & \multicolumn{4}{|c|}{ USD RETURN } \\
ARMA (0,3) \\
\hline SBIC & LogL & AIC & BIC & HQ \\
\hline $\mathbf{- 6 , 6 1 6 1 7}$ & 8987,99 & $-6,627069$ & $-6,616178$ & $-6,623131$ \\
\hline
\end{tabular}

Source: Authors' Compilation

According to the ARMA election results, the ARMA structure of the dollar return series was determined as $(0,3)$, that is, AR (0), MA (3). The ARCH LM test statistic value is calculated using the residual series obtained from the ARMA model. ARCH LM test statistics values were calculated at different led lag numbers for the USD return residual series. The results found are shown in Table 6 .

Table 6: ARCH LM Test Results

\begin{tabular}{|c|c|c|c|c|}
\hline & $\begin{array}{c}\text { Lag } \\
\text { coefficient }\end{array}$ & F Statistics & Observation $\boldsymbol{R}^{2}$ & RESULTS \\
\hline \multirow{3}{*}{ USDR } & 1 & $324,6201^{* * *}$ & $434,4010^{* * *}$ & \multirow{2}{*}{ There is heterosdastic. } \\
\cline { 2 - 4 } & 5 & $89,67279^{* * *}$ & $385,3661^{* * *}$ & \\
\cline { 2 - 4 } & 10 & $45,35222^{* * *}$ & $389,6787^{* * *}$ & \\
\cline { 2 - 4 } & 15 & $30,78017^{* * *}$ & $396,2024 * * *$ & \\
\hline
\end{tabular}

Source: Authors' Compilation

ARCH-LM test statistics values and $\mathrm{R}^{2}$ values of errors calculated by considering different lags are statistically significant at $1 \%$ significance level. With these results, the null hypothesis claiming that there is no variance effect is rejected. That is, it is concluded that there is an ARCH effect in the dollar return series. Volatility needs to be modeled at this stage. For the dollar return series, ARCH (p), GARCH (p, q) models, which are among the conditionally heteroskedasticity variance models, are constructed and calculations are made according to the lag lengths p: 1,2,3 and q: 1,2,3. In order to choose the most suitable model, firstly, the parameters must be meaningful, and the parameter constraint conditions must be met. The variance equation coefficients of conditionally heteroskedasticity variance models must be positively valued, and the sum of these coefficients must be less than one. The low one of the Akaike Information Criteria (AIC) and the Schwartz Bayesian Information Criteria (SBIC) and 
the higher likelihood ratio (OO) of the models that fulfill the parameter criteria are selected as the most suitable model. Models with these criteria have been determined for the series and are shown in Table7.

Table 7: Most Suitable GARCH Models

\begin{tabular}{|c|c|}
\hline Series & USDRV \\
\hline Model & GARCH $(2,2)$ \\
\hline Parametre & $8,44 \mathrm{E}-08^{* * *}$ \\
\hline$\alpha_{0}$ & $0,175264^{* * *}$ \\
\hline$\alpha_{1}$ & $-0,164219 * * *$ \\
\hline$\alpha_{2}$ & $1,635376^{* * *}$ \\
\hline$\beta_{1}$ & $-0,647071^{* * *}$ \\
\hline$\beta_{2}$ & - \\
\hline$\gamma_{\mathrm{I}}$ & $-6,954745$ \\
\hline AIC & $-6,943854$ \\
\hline SBIC & $94,32,157$ \\
\hline OO & \\
\hline$* * *$ indicates $1 \%, * *$ indicates $5 \%, *$ indicates $10 \%$ of significance level.
\end{tabular}

Source: Authors' Compilation

The GARCH $(2,2)$ model has been determined as the most suitable model for the dollar return series. ARCH-LM test was performed again to see whether the predicted models removed the ARCH effect in the series, and it was determined that the variance problem existing in the series was eliminated.

\subsection{Granger Causality Test Results}

In order to investigate the causality relationship between USD return series volatility and BIST industrial, financial, service, technology sector indices and BIST 100 index returns, it was first examined whether the time series is stationary or not. The USD volatility series obtained from the GARCH model, the BIST sector indices' stability, and the BIST 100 index were investigated using Augmented DickeyFuller (ADF) and the Philips Perron (PP) unit root tests. Unit root test results are presented in Table 8.

Table 8: Unit Roots Tests

\begin{tabular}{|c|c|c|c|c|c|}
\hline \multirow{2}{*}{ Series } & \multirow{2}{*}{ Level } & \multicolumn{2}{|c|}{$\begin{array}{c}\text { Augmented Dickey-Fuller } \\
\text { (ADF) Testi }\end{array}$} & \multicolumn{2}{c|}{$\begin{array}{c}\text { Philips-Perron } \\
\text { (PP) Testi }\end{array}$} \\
\cline { 3 - 6 } & & Intercept & Trend Intercept & Intercept & Trend Intercept \\
\hline USDRV & Level & $-10,99555^{* * *}$ & $-11,2001^{* * *}$ & $-10,22691^{* * *}$ & $-10,72135^{* * *}$ \\
\hline RBIST 100 & Level & $-52,6438^{* * *}$ & $-52,6344^{* * *}$ & $-52,64198^{* * *}$ & $-52,63276^{* *}$ \\
\hline RBIST Ind. & Level & $-33,89187^{* * *}$ & $-33,8866^{* * *}$ & $-50,7070^{* * *}$ & $-50,6986^{* * *}$ \\
\hline RBIST Serv. & Level & $-50,9717^{* * *}$ & $-50,9666^{* * *}$ & $-51,0077^{* * *}$ & $-51,0025^{* * *}$ \\
\hline RBIST Fin. & Level & $-53,3017^{* * *}$ & $-53,2933^{* * *}$ & $-53,2996^{* * *}$ & $-53,2895^{* * *}$ \\
\hline
\end{tabular}

67 | P a g e Journal of Corporate Governance, Insurance, and Risk Management | 2021, VOL. 8, Series. 1 


\begin{tabular}{|c|c|c|c|c|c|}
\hline RBIST Tec & Level & $-51,3397^{* * *}$ & $-51,3329^{* * *}$ & $-51,3344^{* * *}$ & $-51,3270^{* * *}$ \\
\hline \multicolumn{5}{|c|}{ Critical Values } \\
\hline$\% 1$ & $-3,4325$ & $-3,9614$ & $-3,4325$ & $-3,9614$ \\
\hline$\% 5$ & $-2,8624$ & $-3,4114$ & $-2,8624$ & $-3,4114$ \\
\hline$\% 10$ & $-2,5672$ & $-3,1275$ & $-2,5672$ & $-3,1275$ \\
\hline
\end{tabular}

*** indicates $1 \%$, ** indicates $5 \%$, * indicates $10 \%$ of significance level.

Source: Authors' Compilation

When Table 8 is examined, according to the unit root test results of the series with fixed and fixed and trending effects, the series do not have unit roots in both ADF and PP techniques. Thus, it was concluded that the null hypothesis that there is a unit root in the series is rejected and that the level values of the series are stable I (0). After determining the stability of the series, to investigate the causal relationship between the USDRV, BIST 100, BIST Industry, (BIST Ind.) BIST Service (BIST Serv.), BIST Financial (BIST Fin.) and BIST technology (BIST Tec.) the VAR Granger causal test was applied. In order to determine the source of causality based on the vector autoregressive (VAR) model, the following models have been estimated.

$$
\begin{aligned}
& U S D R V_{t}=\alpha_{1}+\sum_{i=1}^{n} \beta_{1 i} U S D R V_{t-i}+\sum_{i=1}^{n} \gamma_{1 i} R B I S T 100_{t-i}+\varepsilon_{1 t} \\
& R B I S T 100_{t}=\alpha_{2}+\sum_{i=1}^{n} \beta_{2 i} \operatorname{RBIST} 100_{t-i}+\sum_{i=1}^{n} \gamma_{2 i} \operatorname{USDRV}_{t-i}+\varepsilon_{2 t} \\
& \operatorname{USDRV}_{t}=\alpha_{3}+\sum_{i=1}^{n} \beta_{3 i} \operatorname{USDRV}_{t-i}+\sum_{i=1}^{n} \gamma_{3 i} \operatorname{RBISTInd}_{t-i}+\varepsilon_{3 t} \\
& \operatorname{RBISTInd}_{t}=\alpha_{4}+\sum_{i=1}^{n} \beta_{4 i} \operatorname{RBISTInd}_{t-i}+\sum_{i=1}^{n} \gamma_{4 i} \operatorname{USDRV}_{t-i}+\varepsilon_{4 t} \\
& U S D R V_{t}=\alpha_{5}+\sum_{i=1}^{n} \beta_{5 i} U S D R V_{t-i}+\sum_{i=1}^{n} \gamma_{5 i} \operatorname{RBISTSERV} V_{t-i}+\varepsilon_{5 t} \\
& \operatorname{RBISTServ}_{t}=\alpha_{6}+\sum_{i=1}^{n} \beta_{6 i} \operatorname{RBISTServ}_{t-i}+\sum_{i=1}^{n} \gamma_{6 i} \operatorname{USDRV}_{t-i}+\varepsilon_{6 t} \\
& \operatorname{USDRV}_{t}=\alpha_{7}+\sum_{i=1}^{n} \beta_{7 i} \operatorname{USDRV}_{t-i}+\sum_{i=1}^{n} \gamma_{7 i} \text { RBISTFin }_{t-i}+\varepsilon_{7 t}
\end{aligned}
$$




$$
\begin{gathered}
\text { RBISTFin }_{t}=\alpha_{8}+\sum_{i=1}^{n} \beta_{8 i} \text { RBISTFin }_{t-i}+\sum_{i=1}^{n} \gamma_{8 i} \text { USDRV }_{t-i}+\varepsilon_{8 t} \\
\text { USDRV }_{t}=\alpha_{9}+\sum_{i=1}^{n} \beta_{9 i} \text { USDRV }_{t-i}+\sum_{i=1}^{n} \gamma_{7 i} \text { RBISTTec }_{t-i}+\varepsilon_{9 t} \\
\text { RBISTTec }_{t}=\alpha_{10}+\sum_{i=1}^{n} \beta_{10 i} \text { RBISTTec }_{t-i}+\sum_{i=1}^{n} \gamma_{10 i} \text { USDRV }_{t-i}+\varepsilon_{10 t}
\end{gathered}
$$

After estimating the equations, the F statistics and probability values obtained from the Walt test applied together with the independent variables' coefficients for each dependent variable are shown in

\begin{tabular}{|c|c|c|c|}
\hline Hypotheses & F Value & Probability & Direction of Causality \\
\hline $\begin{array}{l}\text { USD Return Volatility is not the Granger cause } \\
\text { of the BIST } 100 \text { Index Return. }\end{array}$ & 1,85671 & 0,134 & \multirow[t]{2}{*}{ USDRV $\longleftarrow$ BIST100 } \\
\hline $\begin{array}{l}\text { BIST } 100 \text { Index Return is not the Granger } \\
\text { cause of USD Return Volatility. }\end{array}$ & 2,6917 & $0,044^{* *}$ & \\
\hline $\begin{array}{l}\text { USD Return Volatility is not the Granger cause } \\
\text { of the BIST Industry Index Return. }\end{array}$ & 2,5517 & $0,054^{*}$ & \multirow{2}{*}{ USDRV $\longrightarrow$ BISTIND } \\
\hline $\begin{array}{l}\text { BIST Industry Index Return is not the Granger } \\
\text { cause of USD Return Volatility. }\end{array}$ & 0,90241 & 0,439 & \\
\hline $\begin{array}{l}\text { USD Return Volatility, is not Granger cause of } \\
\text { Bist Service Index Return }\end{array}$ & 2,61978 & $0,049 * *$ & \multirow{2}{*}{ USDV $\longrightarrow$ BISTSERV } \\
\hline $\begin{array}{l}\text { BIST Service Index Return is not Granger } \\
\text { cause USD Return Volatility. }\end{array}$ & 7,58353 & 5.E-05 & \\
\hline $\begin{array}{l}\text { USD Return Volatility is not Granger cause } \\
\text { BIST Finance Index Return. }\end{array}$ & 4,579 & $0,008 * * *$ & \multirow{2}{*}{ USDRV $\longleftrightarrow$ BISTFIN. } \\
\hline $\begin{array}{l}\text { BIST Finance Index Return is not Granger } \\
\text { cause USD Return Volatility. }\end{array}$ & 4,1637 & $0,015^{* * *}$ & \\
\hline $\begin{array}{l}\text { USD Return Volatility, is not Granger cause } \\
\text { BIST Technology Index Return. }\end{array}$ & 5,0071 & $0,001^{* * *}$ & \multirow{2}{*}{ USDRV $\longrightarrow$ BISTTEC } \\
\hline $\begin{array}{l}\text { BIST Technology Index Return is not Granger } \\
\text { cause USD Return Volatility. }\end{array}$ & 0,6782 & 0,565 & \\
\hline
\end{tabular}
Table 9.

Table 9: Granger Causality Test Results

Table 9 presents the findings of the Granger causality test. The table shows that the causality relationship is uni- directional from the exchange rate return volatility series to the service, technology, and industry sector indices. There is a bidirectional causality relationship between the financial sector index and the exchange rate return volatility series. 


\section{CONCLUSION}

Theoretically, changes in exchange rates can change stock returns because changes in exchange rates change the firms' profit. This situation affects stock returns. This means that the causality aspect is from exchange rates to stock prices and is explained by the traditional model. In the portfolio balance approach, an increase in domestic stock prices creates an increase in domestic income, which leads to an increase in the demand for money and thus in interest rates. High-interest rates will also cause capital inflows, causing the country's currency to appreciate. Thus, the direction of the relationship between stock prices and exchange rates can be from stock prices to exchange rates. The study aims to determine which of the traditional approaches or portfolio balance theories are valid for the Turkish economy's main sectors. For this purpose, BIST 100, BISTIND, BISTSERV, BISTTEC, BISTFIN indices were taken. As the exchange rate, the United States Dollars (USD) value in Turkish Lira (TL) has been taken. Exchange rate return is modeled with the GARCH $(2,2)$ model. In the study, daily data for the period between 07.01.2011 - 15.10.2020 were analyzed.

Granger causality test was used to investigate the causality relationship between stock indices and exchange rate return volatility. The study shows that the causality relationship is uni-directional from the exchange rate return volatility series to the service, technology, and industry sector indices. There is a bidirectional causality relationship between the financial sector index and the exchange rate return volatility series. It is striking that the causality relationship between the BIST 100 index and the exchange rate differs from the others. The direction of the relationship is from the BIST100 index to the exchange rate. According to this result, one can see that changes in the dollar exchange rate have an effect on the decisions of the investors who would invest in the relevant index. It is thought the fact that the dollar is seen as an investment tool and has an effect on the sales and resource structure of the companies included in the relevant indices has led to the emergence of such causality. The causality test results show that the traditional theory, which is one of the theories explaining the relationship between stocks and exchange rates, is valid in The Turkey Stock Exchange sector indices. Considering the number of shares held by foreigners on the Turkish stock exchange, the results obtained will help foreign portfolio investors concerned about exchange rate risk. Exchange rate volatility in Turkey should be carefully monitored by investors. For both domestic and foreign investors in the stock market, it will be appropriate for policy makers to take decisions by taking into account the sensitivity of investors.

The fact that the value of the American dollar (USD) against the Turkish Lira (TL) as the exchange rate is the only variable, constitutes the study's limitation. Future studies can test whether the structural breaks create a difference in the relationship between index returns and exchange rate. 


\section{REFERENCES}

Abdalla, I. and Murinde, V. (1997), "Exchange rates and stock price interactions in emerging financial markets: evidence on India, Korea, Pakistan and the Philippines”, Applied Financial Economics, 7, 25-35.

Akdag S., and Yıldırım H. (2019).,'"Relationship between dollar exchange rate nd selected BISTsector indices: asymmetric causaliy analysis”, The Academic Elegance Issue: 12 Volume: 6 , 409-425.

Andrikopoulos, A., Samitas, A. nd Kougepsakis, K. (2014), “Volatility transmission across currency and stock markets: GIIPS in crisis”, Applied Financial Economics, 24(19), 1261-1283.

Akbar, M., Iqbal, F., and Noor, F. (2019),” Bayesian analysis f dynamic linkages among gold price, stock prices, exchange rate nd interest rate in Pakistan”, Resources Policy, 62, 154- 164.

Alacahan D. N. and Akarsu Y. (2019), "Time series analysis for the effect of exchange rate risk on BIST100 index: case of Turkey”, Journal of Life Economics, 6(2), 133-150.

Aliyu, S. R. (2009), "Stock prices and exchange rate interactions in Nigeria: a maiden intra-global financial crisis investigation”.IUP Journal of Financial Economics, 7(3/4), 7-23.

Amihud, Y. (1994), "Exchange rrtes and the valuation of equity shares". In Exchange Rate And Corporate Performance, Edited by: Amihud, Y. and Levich, R. M. 49-59. New York: Irwin.

Ayvaz, Ö. (2006), “The causality relationship between exchange rate and stock prices”. Gazi University Journal of Economics and Administrative Sciences, 8(2), 1-14.

Bahmani-Oskooee, M. and Sohrabian, A. (1992), Stock prices and effective exchange rate f dolar”. Applied Economics, 24(4), 459-464.

Baranidharan S.,and Alex A., (2020), "Volatility spillover of exchange rate on stock market evidence from South Africa”, Asian Journal of Economics, Finance and Management 2(3): 26-34.

Bartov, E. and Bohnar, G. (1994), "Firm valuations, earnings expectations nd the exchange rate exposure effect”. Journal of Finance, 49: 1755-1785-.

Berke, B. (2012), “Exchange rate and IMKB100 index relationship: a new test”. Finance Journal, 163, 243- 257.

Belen, M. and Karamelikli, H. (2016), "Investigating the relationship between stock returns and foreign exchange rate in Turkey: ARDL Approach ”. Istanbul University Journal of the School of Business, 45(1), 34-42.

Branson, W. H. (1983), “A model of exchange-rate determination with policy reaction: evidence from monthly data”, NBER Working Paper, No: 1135.

Bollerslev, T. (1986), "Generalized autoregressive conditional heteroskedasticity”, Journal of Econometrics, 31, 307-327.

Ceylan, S. and Şahin Y. B. (2015). Relationship between stock prices and exchange rate. International Journal of Social Science, 37, 399-408. 
Dornbusch, R. and Fischer, S. (1980), “Exchange rates and the current account”, American Economic Review, 70(5), 960-971.

Engle R., (1982), Autoregressive conditional heteroscedasticity with estimates of the variance of united kingdom inflation, Econometrica Vol. 50, No. 4 (Jul., 1982), pp. 987-1007.

Engle, R. (2001), "GARCH 101: The use of ARCH/GARCH models in applied econometrics." Journal of Economic Perspectives, 15 (4): 157-168.

Eyuboğlu, S., and Eyuboğlu, K. (2018), "Examining the relationships among the borsa istanbul sector indices and exchange rates: ardl model”. Omer Halis Demir University Academic Review of Economics and Administrative , 11(1), 8- 28.

Ghazali, M. F., Ismail, W., Yasoa, M. R., andLajuni, N. (2008), “Bivariate causality between exchange rates and stock prices in Malaysia”. The International Journal of Business and Finance Research, 2(1), 53- 59.

Granger C., (1988), “Causality, cointegration, and control”, Journal of Economic Dynamics and Control, 1988, Vol. 12, Issue 2-3, 551-559.

Gujarati, D.N. (2001). Basic Econometrics (U. Senesen \& G.G. Senesen Translated). Istanbul: Literatür Publishing.

Horobet, A. and Ilie, L. (2007), "On the dynamic link between stock prices and exchange rates: evidence from Romania”. Working paper, Munich Personal RePEc Archive.

Ilarslan, K. (2018), "An empirical study on the relationship between exchange rates and stock exchange index in the short and long term", Journal of Hacettepe University Faculty of Economics and Administrative Sciences, 36 (1), 83-104.

Johnston K, and Scott E (2000), "GARCH models and the stochastic process underlying exchange rate price changes”. J. Finan. Strateg. Decis., 13(2), Summer.

Kabir, S. H., Bashar, O. K., and Masih, A. M. M. (2014), "Is domestic stock price cointegrated with exchange rate and foreign stock price?: Evidence from Malaysia”. The Journal of Developing Areas, 48(3), 285-302.

Kapusuzoglu, A. and Ibicioglu, M. (2010), “Analysis of the relationship etween the exchange rate and stock prices: Turkey app”., Accounting Science World, 12(4), 135-153.

Kayral, I. E. (2020), "Examining the relationships between BIST city indices and exchange rates: an ARDL bound testing application.”, IBAD Journal of Social Sciences Issue, 6, 272- 284.

Kendirli, S.,and Çankaya, M. (2016), “The effect of currency rate and inflation on bist banking index”, MANAS Journal of Social Studies, 5(3), 2015- 227.

Kutty, G. (2010), “The relationship between exchange rates and stock prices: the case of Mexico”, North American Journal of Finance and Banking Research, 4(4) 1-12.

Lean, H. H., Narayan, P., and Smyth, R. (2011), "Exchange rate and stock price interaction in major Asian markets: evidence for individual countries and panels allowing for structural breaks.’The Singapore Economic Review, 56(02), 255-277. 
Lee, C.-H., Doong, S.-C., and Chou, P.-I. (2011), "Dynamic correlation between stock prices and exchange rates”, Applied Financial Economics, 21(11), 789-800.

Mroua M., andTrabelsi L.,(2020), "Causality and dynamic relationships between exchange rate and stock market indices in BRICS countries Panel/GMM and ARDL analyses”, Journal of Economics, Finance and Administrative Science Vol. 25 No. 50, 395-412.

Obben J., Pech A., and Shakur S. (2006) "“Analysis of the relationship between the share market performance and exchange rates in New Zealand: A cointegrating VAR approach”, New Zealand Economic Papers, 40:2, 147-180.

O’Donnell, M.,andMorales, L. (2009), "Volatility spillovers between stock returns and foreign exchange rates: evidence from four Eastern European Countries”, Int J Business, 12, 1-20.

Ozdemir L. (2020), “Asymmetric causality relationship between the stock market and the exchange rate in BRICS-T “,IV. International Applied Social Sciences Congress 22nd -24th October 2020, 310322.

Pekkaya, M., and Bayramoglu M. F. (2008), “Causality test between exchange rate and stock prices: an analysis on USD/YTL, ISE 100 and S\&P 500”, Accounting Finance Journal, 163- 176.

Savaş, I. and Can I. (2011), "Euro-Dollar parity and effects of the real exchange rates on the index of IMKB 100”. Eskişehir Osmangazi University Journal of Economics and Administrative Sciences, 6 (1), 323-339.

Sharma, N. (2016), “Causal relation between stock return and exchange rate: evidence from India”, Global Journal of Management and Business Research, 15 (11), 27-32.

Sikhosana,A., and Goodness C. Aye, (2018). “Asymmetric volatility transmission between the real exchange rate and stock returns in South Africa", Economic Analysis and Policy, Volume 60, 18.

Sui, L. andSun, L. (2016), "Spillover effects between exchange rates and stock prices: evidence from BRICS around the recent global financial crisis”, Research in International Business and Finance, 36, 459-471.

Senol Z., (2020), "Volatility spillover between stock market, exchange rate and oil prices”, Accounting Science World Journal, Aralık, 22(4), 629-647.

Tabak, B.M. (2006), “The dynamic relationship between stock prices and exchange rates: evidence for Brasil”, Bank of Brasil Working Paper Series 124.

Tian, G. G., and Ma, S. (2010). "The relationship between stock returns and the foreign exchange rate: The ARDL approach”, Journal of the Asia Pacific Economy, 15(4), 490- 508.

Uğur A., and Bingol N., (2020). "The direction of the stock and foreign exchange relations: a research on Turkey”, Academic Review of Economics and Administrative Sciences , 13(4) 624-636.

Urkmez, E., and Karatas, T. (2017), “Determining the dynamic relationship between borsa istanbul 100 index and exchange rates”, Journal of Academic Social Research, 5 (45), 393- 409. 
Walid, C., Chaker, A., Masood, O. and Fry, J. 2011. "Stock market volatility and exchange rates in emerging countries: A Markov-State Switching approach”, Emerging Markets Review, 12(3), 272- 292. 